\title{
Apontamentos sobre a implantação do protestantismo no Brasil: história, cultura e tradição
}

\author{
Fernando Ripoli*
}

\section{RESUMO}

O protestantismo no Brasil tem sido um campo de estudo por muitos pesquisadores, sejam eles(as), historiadores, sociólogos, filósofos, antropólogos e cientistas da religião. Nosso objetivo neste pequeno ensaio é repaginar alguns apontamentos sobre o protestantismo no Brasil. Em primeiro lugar, traremos uma definição de protestantismo. Em seguida, apresentaremos as tentativas de implantação dos protestantes em solo tupiniquim, abordando sua militância missionária. Por fim, trabalharemos com os registros dos dias atuais sobre este período para fazer uma leitura do protestantismo de imigração e missão na América Latina.

Palavras-chaves: História; Protestantismo; Tupinambás; Brasil Colonial e Missão.

\section{NOTES ON THE IMPLEMENTATION OF PROTESTANTISM IN BRAZIL: HISTORY, CULTURE AND TRADITION.}

\section{ABSTRACT}

Protestantism in Brazil has been a field of study by many researchers, whether they are historians, sociologists, philosophers, anthropologists or religion scientists. In this short essay some notes on Brazilian Protestantism are presented. First and foremost, we will present a definition

* Docente na Fateo/UMESP. Doutorado em Ciências da Religião pela Escola de Comunicação, Educação e Humanidades da Universidade Metodista de São Paulo- UMESP (2016). Mestre em Ciências da Religião pela UMESP (2012-2014). Pós-graduação em História do Protestantismo (lato-sensu) pela FTBSP (2009-2011), Pós-graduação em Ciências da Religião (lato-sensu) pela PUCSP (2011-2013). Bacharel em Teologia pela Faculdades EST (2004-2008). Formação Pedagógica em História pelo CLARETIANO (2013-2014). Graduação em História (Licenciatura) pelo CLARETIANO (2014-2017). Graduando em Pedagogia pela UNICSUL (2017). Orientando da Dra. Suely Xavier dos Santos/UMESP. Bolsista UMESP. E-mail: fernando.ripoli@metodista.br / lattes: http:// lattes.cnpq.br/5951403420648430 
of Protestantism. Next, we will attempt to implant the Protestants on Tupinikim soil, addressing its missionary militancy. Finally, we will work with nowadays materials about this period to perform a reading of the Protestantism of immigration and mission in Latin America.

Keywords: History; Protestantism; Tupinambás; Colonial Brazil and Mission.

Comparando com a plenitude do universo católico, o protestantismo Aparece como um truncamento radical, uma redução ao essencial, às expensas de uma grande riqueza de conteúdos religiosos. Peter Berger, O Dossel Sagrado.

\section{Considerações iniciais}

O protestantismo no Brasil se divide basicamente em duas partes, segundo Camargo ${ }^{1}$ : o protestantismo de emigração que era intensivamente étnico e o protestantismo de missão, que se caracterizava mais como proselitista (CAMARGO, 1973, p.105-106).

Gedeon Alencar ${ }^{2}$ apresenta-nos dois tipos de protestantismo: o protestantismo pentecostal de vertente escatológica e o protestantismo contemporâneo. O primeiro chega propriamente no Brasil em 1910 com Luigi Franciscon fundando a "Congregração Cristã do Brasil" e em 1911 com Daniel Berg e Adolf Gunnar Vingren fundando a "Missão de fé Apostólica" que anos após a sua fundação se conciliou na "Assembleia de Deus". Esse grupo cresce ano após ano, assim como o protestantismo contemporâneo, que é conhecido como "gospel” ou mais "light", sem doutrina, isento de ensino teológico e sem adesão religiosa, como se fosse um protestantismo sem protestos e sim para os benefícios próprios dos adeptos da igreja. $\mathrm{Na}$ verdade os protestos que os pastores fazem vão sempre em direção de beneficiar o seu público (ALENCAR, 2005, p.37-38).

Aparentemente Alencar está ponderando os neopentecostais e suas propagandas de marketing como se fossem verdadeiras empresas

1 CAMARgO, F.P. Cândido. Católicos, Protestantes, Espiritas. São Paulo: Vozes, 1973, pg. 105-106.

2 ALENCAR, Gedeon. Protestantismo Tupiniquim - Hipóteses sobre a (não) contribuição evangélica à cultura brasielira. São Paulo: Arte editorial, 2005, pg. 37-38 
evangélicas. É importante saber que estas duas divisões apontadas por Alencar são didáticas e cronologicamente corretas segundo ele.

Consequentemente apresentarei nesse ensaio estas divisões do protestantismo brasileiro segundo Camargo (imigração e missão), pois são de suma importância, além dos dois tipos de protestantismo apresentados por Gedeon Alencar (o protestantismo pentecostal e o protestantismo contemporâneo). A proposta a princípio é assinalar as tentativas de inserção do protestantismo de imigração e missão no Brasil, até porque as temáticas envolverão as relações entre a história e a cultura protestante brasileira.

\section{Protestantismo em contexto}

Segundo uma probabilidade europeia, o protestantismo pode ser descrito como uma religião moderna, $[. .$.$] na qual ao invés do ser hu-$ mano buscar por seus esforços chegar a Deus, característica que se confunde com a própria história das religiões, [...] o ser humano é alvo da busca incansável do amor divino ${ }^{3}$ (SILVA, 2015, p.12-13).

Segundo Elwell (1994, p.194) o conceito protestantismo ${ }^{4}$ designa todo o movimento dentro do cristianismo que se originou na reforma do século XVI e que mais tarde centrou-se nas principais tradições da igreja reformada, como por exemplo - Luterana, Reformada (Calvinista/ Presbiteriana) e Anglicana Episcopal, embora o anglicanismo alegue ser tanto católico quanto protestante. Elwell ainda diz mais:

Este termo deriva-se do "protesto", entregue por uma minoria de autoridades luteranas e reformadas da dieta alemã em Speyer em 1529, numa dissidência causada por uma ordem imposta que proibia a renovação religiosa. O "protesto" era ao mesmo tempo, uma objeção, um apelo e uma afirmação. Perguntava em tons urgentes: "Qual é a igreja verdadeira e santa?"; e asseverou: "Não há nenhuma pregação ou doutrina segura senão aquela que permanece fiel à palavra de Deus. Segundo o mandamento divino, nenhuma outra doutrina deve ser pregada. Todo texto das santas e divinas escrituras deve ser elucidado e explicado por outros textos. Esse livro santo é necessário, em todas as coisas, para o cristão; brilha claramente na sua própria luz e é visto iluminando as trevas. Esta-

SILVA, Haroldo Xavier. Protestantismo e conceitos. São Paulo: Faculdade Batista de São Paulo, 2015., p. 12-13.

4 ELWELL, A. Walter. Enciclopédia Histórica Teológica da Igreja Cristã. (Vol. 3). São Paulo: São Paulo: Vida Nova., p. 194. 
mos resolutos, pela graça de Deus, e com a Sua ajuda, a permanecermos exclusivamente na Palavra de Deus, no santo evangelho contido nos livros bíblicos do Antigo e do Novo Testamento. Somente essa palavra deve ser pregada, e nada que seja contrário a ela. É a única verdade. É o juiz certo de toda doutrina e conduta cristã e não pode nos enganar nem lograr" (ELWELL, 2009, p.194).

$\mathrm{O}$ autor nos apresenta que os luteranos e outros personagens defensores da reforma passaram a ser conhecidos como protestantes após estas declarações citadas acima.

Já Mendonça justifica-nos que o protestantismo é um dos três ${ }^{5}$ principais ramos do cristianismo ao lado do catolicismo romano e das igrejas orientais ou ortodoxas, ele ainda relata que está categorização ${ }^{6}$ é adotada por J. L. Dunstan (1980, p.7). Justamente por esta categorização nos surge um problema, onde colocar o Anglicanismo? Por muitos é entendido como uma comunidade que extrapola o reino unido. Dunstan ressalta que a igreja da Inglaterra resulta sem dúvida da reforma religiosa, mas, como se diz com frequência ficou a meio caminho entre Roma e as igrejas protestantes tanto luteranas como calvinistas. De fato, a ala propriamente dita Anglicana recusa o título de protestante. Contudo, é notório que a igreja Anglicana é significativa por se aproximar bastante dos protestantes em geral, e não se justifica em outra categoria uma vez que o anglicanismo mantém sua uniformidade (DUNSTAN, 1980, p. 8-9).

Poderíamos então estabelecer quatro categorias de igrejas cristãs mundiais, como: a) Igreja Católica Apostólica Romana; b) Igrejas Ortodoxas ou Orientais; c) Igrejas Anglicanas; d) Igrejas Protestantes de imigração e missão.

Mendonça e Prócoro ${ }^{6}$ nos propõem outra separação diferente da citada anteriormente, obviamente nascida da reforma como: (Anglicana, Luterana e Calvinista e etc.), por causa desta repartição é mais adequado falar em "protestantismos" do que em protestantismo brasileiro (MENDONÇA, 2002, p.11-12). Então, os protestantes propriamente ditos são os luteranos e calvinistas que se espalharam pelo mundo em

5 DUNSTAN, J. Leslie. Protestantismo. Lisboa, Verbo, 1980.

6 MENDONÇA, A. Antônio; FILHO, Velasques Prócoro. Introdução ao protestantismo no Brasil. $2^{\circ}$ edição. São Paulo: Loyola, 2002, p. 11 - 12. 
numerosa diversificação, particularmente estes últimos citados. Afinal, protestantes seriam aquelas igrejas que se originaram da reforma ou que, embora surgidas posteriormente, guardam os princípios gerais do movimento reformador de Martim Lutero.

\section{As tentativas de inserção do protestantismo brasileiro}

Quando falamos sobre o protestantismo brasileiro ${ }^{7}$, a complexidade se torna ainda maior, pois, ao emigrarem para a América do Norte estes protestantes europeus passaram por diversas transformações institucionais, teológicas e culturais, que fizeram deles um fenômeno religioso distinto de suas origens históricas mais próximas. Para situarmos neste contexto histórico o protestantismo brasileiro, exige-se, para sua correta compreensão, que esse fluxo seja tomado e mantido sempre presente (MENDONÇA, 2002, p.12).

$\mathrm{Na}$ perspectiva de Jean Crespin, a primeira colônia protestante foi em (1555-1560) e firmou-se ainda que por pouco tempo quando o vice-almirante Nicolas Durand de Villegaignon tomou posse da ilha de Guanabara em frente à atual cidade do Rio de Janeiro com o objetivo de fundar uma França Antártica. Ali Villegaignon se proclamou o rei da América e a ilha foi denominada de "Forte de Coligny" em homenagem ao militar e político huguenote ${ }^{8}$ (CRESPIN, 2007, p. 137-141).

Infelizmente, o empreendimento de Villegaignon foi motivado por uma soma de interesse próprio e estava em busca de fortuna. A França, por sua vez, em busca de terras. Com o crescimento da reforma na França o reformador João Calvino, que enviaria pastores, buscava responder ao desafio missionário.

Os interesses dos franceses não eram simplesmente evangelizatórios, mas também mercantis. As crônicas do pastor Jean de Léry se constituíram numa das principais fontes que possibilitam compreender que, na perspectiva dos índios, os franceses em nada se distinguiam dos portugueses. O diálogo do referido pastor com um indígena exemplifica isso. Um índio ancião teria perguntado ao pastor:

MENDONÇA, Op. cit., p.12.

8 CRESPIN, Jean. As Missões Protestantes. São Paulo: Vozes, p. 137 - 141. 
Porque é que vocês, franceses e portugueses, vieram de tão longe buscar madeira para se esquentarem? Não existe madeira em seus países? Sim, existe - respondeu o pastor - porém não como esta. Além do mais, não a queremos para queimar, mas para tingir as roupas, como fazem vocês com suas cordas de algodão e com suas plumas. E precisam de muita? Sim. No nosso país há comerciantes que têm muito mais telas, facas, tesouras, espelhos e outras coisas do que vocês podem imaginar. Um só deles pode comprar toda a madeira que vem em vários barcos. Ah! O que você me conta é incrível. E esse homem tão rico, nunca morre? Sim. Morre como os demais. E o que se faz então quando morre com todas essas coisas que tem? Ficam para seus filhos, ou senão para seus irmãos ou parentes. Já me dou conta que vocês os franceses são loucos. Cruzam o mar com mil trabalhos e dificuldades... e trabalham com afã para acumular riquezas para seus filhos... Não bastaria a terra que alimenta vocês para alimentá-los a eles também? Nós também temos pais, mães e filhos a quem amamos. Porém confiamos que depois de nossa morte a terra que nos alimentou os alimentará também. Por isso podemos viver sem grandes preocupações (GONZALEZ, 2008, p. 206).

Cézar nos descreve que em 7 de março de 1557, desembarcaria no Brasil $^{9}$ a segunda expedição, composta de cerca de 280 a 300 pessoas, entre as quais estavam doze calvinistas de Genebra que traziam credenciais do próprio Calvino. Entre estes, dois eram pastores, a saber, Pedro Richier e Guilherme Chartier. Na ocasião da chegada destes, Villegaignon causou surpresa a todos pela manifestação de profunda piedade (CÉZAR, 2000, p.37-39).

E após três dias depois da chegada, os dois pastores celebraram o primeiro culto protestante em território brasileiro e no dia 21 de março seguinte de acordo com o ritual simples da Igreja Reformada da França celebrou-se a primeira Santa Ceia protestante em solo brasileiro. Neste mesmo dia, Villegaignon e o ex-dominicano João Cointac professaram publicamente a fé de acordo com a Igreja Reformada francesa, abdicando da fé católico-romana. Cointac não aceitou a simplicidade da celebração da Santa Ceia reformada. Atacou, em especial, a falta de vestimenta sacerdotal adequada. Ante a crítica, ambos os pastores Chartier e Richier declararam a autoridade da escritura (em oposição à tradição) a qual não estabelece regras a este respeito. Afirmaram

9 CÉZAR, L. M. Elber. História da evangelização do Brasil. Viçosa: Ultimato, 2000, p. 37-39. 
ainda que haviam se comprometido em ensinar e viver de acordo com a doutrina reformada de Genebra.

A interferência de Villegaignon no assunto precisa ser entendida no conjunto de suas relações na colônia às quais, desde o início não foram boas. Havia desconfiança de Villegaignon tanto em relação aos índios tamoios quanto aos próprios colonos. Estes inclusive tentaram uma conspiração contra ele. Havendo entre eles católicos e protestantes, aqueles acusavam estes de tentar convertê-los. Estes, por sua vez, acusavam os católicos de lhes oprimirem.

Além disso, Jean de Léry um dos súditos de Villegaignon e que escreveu um longo relato sobre o fato, levantou a hipótese de que o vice-almirante teria recebido cartas de Carlos Guise e outros líderes católicos sobre o que se estaria pensando dele na França. Isso o teria levado a criticar os pastores em questões secundárias (Santa Ceia), ou seja, como um pretexto contra os pastores.

No início, Villegaignon se mostrava propenso à doutrina calvinista e após vários incidentes até mesmo violentos a maioria dos colonos permaneceu do lado dos pastores, enquanto Villegaignon se colocou ao lado de Cointac. A partir daí Chartier foi enviado à França para buscar instruções sobre o conflito junto às autoridades calvinistas.

Entremeio, a tensão aumentou e Richier foi proibido de celebrar os sacramentos e de pregar e os huguenotes, baseados na concepção teocrática calvinista afirmando a apostasia de Villegaignon declararam não mais reconhecê-lo como senhor, mas, como tirano e inimigo da república.

Após estas adversidades, Richier e quinze de seus adeptos se retiraram para o continente e em janeiro de 1558, embarcaram no navio francês Jacques com objetivo de retornar para a França. Logo após partir, no entanto, o navio começou a naufragar e cinco dos calvinistas Jean du Bourdel, MatthieuVerneuil, Pierre Bourdon, André La Fone Jacques Le Balleur tomaram um bote para voltar ao continente com o objetivo de aliviar a carga.

Após doze dias lutando ${ }^{10}$ contra o mar, tempestades e fome, conseguiram alcançar o continente, mas acabaram presos por Villegaignon que desconfiava que o retorno deles se devesse a uma armadilha contra

10 CRESPIN, Jean. A tragédia de Guanabara. São Paulo: Cultura Cristã, 2007, p.155. 
ele. Após alguns dias os calvinistas foram presos e questionados sobre vários assuntos teológicos, para que em doze horas fossem apresentadas respostas concernentes as suas afirmações (CRESPIN, 2007, p.155).

Destes incidentes originou-se uma confissão de fé conhecida como: "Confessio Fluminensis" e nos chama a atenção a profundidade teológica desta confissão de fé escrita em tão pouco tempo e nela estão contidas questões sobre o que criam a respeito de Deus, Jesus Cristo, Espírito Santo, os sacramentos, livre arbítrio, perdão de pecados, imposição de mãos, casamentos, votos monásticos, os santos e pessoas falecidas.

Para Velásquez está primeira tentativa de estabelecimento do protestantismo em solo brasileiro foi movida pela busca de liberdade religiosa que não existia na França e também nos apresenta que o evento está no contexto da corrida das grandes potências europeias pelo poder. Finalmente podemos finalizar relatando que os huguenotes ${ }^{11}$ não se interessavam pela tarefa missionária junto aos índios, aliás, quando Villegaignon queria expulsá-los da ilha para o continente, protestaram afirmando que em sã consciência, eles não podiam se retirar com os selvagens totalmente ignorantes da religião cristã (CÉZAR, 2000, p. 39).

Segundo Mendonça ${ }^{12}$, a segunda tentativa dos protestantes no Brasil se deu entre os protestantes holandeses que se estabeleceram no Nordeste entre 1630 e 1654 . Era semelhante à francesa do século anterior, que teve motivação comercial e neste aspecto as intenções da Holanda também não se diferenciavam muito das de Portugal (MENDONÇA, 2002, p. 12).

Aliás, é digno de registro que durante o século XVI, Portugal passou a extrair escravos negros de Angola depois de ter sido banido de outras regiões pelos traficantes de outros países europeus e após invadirem o Nordeste os holandeses também se apoderaram de Angola tornando este país a principal região de aprisionamento de escravos. Ou seja, fica claro que a Holanda continuou o modelo mercantil e escravocrata português.

\footnotetext{
11 CÉSAR, L. M. Elber. História da evangelização do Brasil, dos Jesuitas aos Neopentecostais. Viçosa: Ultimato, pg. 39

12 MENDONÇA, G. Antônio. Introdução ao protestantismo no Brasil. $2^{\circ}$ edição. São Paulo: Loyola, 2002, p.12.
} 
Após a expulsão dos holandeses, por sua vez, Salvador Correia de Sá foi nomeado governador e capitão de Angola. Ele então partiu do Rio de Janeiro com a missão de reconquistar a região de Angola e Correia de Sá foi bem sucedido de forma que restabeleceu o tráfico de escravos para o Brasil. De certo que, em três anos de governo sob Fernandes Vieira, sucessor de Correia de Sá, bateu-se o recorde de tráfico de escravos para o Brasil. Este fato evidencia a importância de Angola para o Brasil e tanto no período português quanto no período do Nordeste holandês.

Faz-se, portanto, necessário contextualizar as pretensões e ações da Holanda no Brasil, no entanto, no final do século XVI os holandeses aliados aos ingleses passam a exercer predomínio marítimo depois da derrota imposta à armada espanhola (1598). E o clima entre Holanda e Espanha era de guerra e inimizade.

De outro lado, em 1621, a Holanda deu um passo importante com a criação da Companhia das Índias Ocidentais com o objetivo de realizar expedições na costa nordeste do Brasil. Isso significava um confronto com a Espanha que desde 1580 até 1640 dominava sobre Portugal e, por extensão, sobre o Brasil (Interlúdio Espanhol) e através da Companhia das Índias Ocidentais a Holanda realizou uma tentativa precária na Bahia de apoderar-se de espaços no Brasil.

Contudo, obteria êxito somente em 1630 ao tomar Recife e, logo em seguida, Olinda expandindo paulatinamente o espaço e a partir do ano de 1641 a Holanda dominaria uma das quatorze capitanias portuguesas no Rio São Francisco no sul de Alagoas por uma extensão de cerca de 1,5 mil quilômetros.

A ação pastoral e missionária dos holandeses no Brasil precisa ser compreendida à luz da concepção reformada de teocracia. Seguindo a tradição reformada os conselhos paroquiais eram compostos por anciãos e tinham a incumbência de tarefas administrativas, enquanto os diáconos tinham a tarefa de assistir aos necessitados. Cerca de quarenta pastores e oito missionários atuaram nestas congregações. Também havia o ministério especial dos consoladores de enfermos que realizavam visitas pastorais, mas também catequeses e em caso de necessidade também ensinavam. 
Segundo esta concepção, tanto a vida particular quanto a pública deveriam estar subordinadas aos mandamentos divinos conforme as Sagradas Escrituras, pois, isso significava que deveria haver uma interação entre ministério eclesiástico e autoridade civil ${ }^{13}$ (BASTIAN, 1988, p. 467-471).

A partir da compreensão teocrática, com sede em Recife foi criado um consistório para o governo da Igreja. Realizaram-se dezenove reuniões do presbitério e quatro assembleias sinodais. Toda a estrutura eclesiástica estava sob supervisão direta da Igreja Reformada da Holanda e então, criou-se concílios políticos no Recife e na Paraíba com a finalidade de examinar documentos de identidade, expedir e receber cartas de transferência, celebrar casamentos, mas também, de julgar casos de comportamento moral no espírito da disciplina e doutrina puritana disciplinadora.

Visando à cristianização da população indígena, os holandeses adotaram o sistema jesuítico de fixação das populações nômades em aldeias e em 1638, Davi Doorenslaer torna-se o primeiro missionário a dedicar-se à evangelização de indígenas na capitania da Paraíba e dois anos mais tarde os primeiros índios foram admitidos à celebração da Santa Ceia, cuja participação na perspectiva reformada indica maturidade espiritual.

Também foi composto um catecismo trilíngue (tupi, holandês e português), embora não viesse a ser divulgado por objeções formais da igreja na Holanda. Comparativamente com a evangelização inquisitorial católico-romana portuguesa e espanhola a tolerância religiosa se constitui marca holandesa numa época em que a Europa estava mergulhada na terrível Guerra dos Trinta Anos (1618-1648) iniciada por motivos religiosos ${ }^{14}$ entre católicos e protestantes (BASTIAN, 1988, p. 472-513).

Nassau concedeu liberdade religiosa autorizando os cultos católicos e judaicos ao lado dos calvinistas, como exemplo da liberdade religiosa no "nordeste holandês" que foi a abertura da primeira sinagoga da América do Sul (BREDA, 2007, p. 22).

13 BASTIAN, Jean-Pierre. O Protestantismo na América Latina. São Paulo: Paulinas, 1998, p. $467-471$.

14 BASTIAN,Op. Cit., p. $472-513$. 
De outro lado, embora a ética calvinista defendesse a dignificação do trabalho e santificação da vocação no sentido de substituir o trabalho escravo pelo trabalho livre, sob pressão dos interesses econômicos, escravos fugitivos foram recapturados devido à falta de mão de obra nos canaviais.

Aliás, percebe-se que também em outros lugares a ética protestante não foi observada em nome dos interesses econômicos. Assim, por exemplo, os próprios holandeses na Ilha de Curaçau, os dinamarqueses nas Ilhas Virgens, os ingleses nas pequenas Antilhas buscaram a mão de obra escrava de origem africana para desenvolver a economia calcada na cana-de-açúcar.

Seguindo o exemplo das igrejas espanhola e portuguesa, também as igrejas protestantes tomaram posição de legitimação dos interesses coloniais, pois, é somente no final do século XVIII que metodistas e, pouco mais tarde, batistas desenvolveriam uma evangelização de caráter antiescravagista.

A rigor, o discurso antiescravagista somente começa por influência pietista, que sacudiu as consciências cristãs a respeito do tema, e por parte dos revolucionários franceses que defendiam os direitos da pessoa. Todavia, o fracasso da Holanda no Brasil não se deve, contudo, ao insucesso da Igreja, mas ao envolvimento do país nas turbulências na Europa e em 1654, os holandeses deixaram o Brasil. Mas, ainda assim, certas concepções calvinistas permaneceriam arraigadas profundamente na mente de populações indígenas nordestinas.

\section{O protestantismo, os missionários e a religião dos tupinambás (índios)}

O ponto de partida de uma investigação sobre as "religiões" na América antes de 1492 ou de 1550 encontra-se nos registros de Pierre Clastres, antropólogo e etnólogo francês. Clastres, em sua obra "A Sociedade contra o Estado - Pesquisas de Antropologia Política" aponta trinta etnias indígenas importantíssimas para a compreensão deste cenário no Brasil Colonial, entre elas, a etnia dos Tupinambás. Clastres colocou-se assim entre outros pesquisadores e alguns historiadores/ 
antropólogos ${ }^{15}$ que já fizeram menção da existência de "religiões" na América (SALDANHA, 2013, p.38-41).

Wachholz (2008, p.9-12) relata-nos que os povos que não reconheciam ou cultuavam deuses ou que não tinham calendários e espaços para culto como os tupinambás, por exemplo, identificavam espíritos e forças invisíveis e tinham também diversas crenças sobre a vida, a morte, a doença e o mal ${ }^{16}$.

Uma parte importante do que sabemos sobre as religiões indígenas são as relações das populações indígenas com a nova religião que chegava com os protestantes. Ao conhecermos os escritos dos missionários ou dos indígenas ${ }^{17}$ convertidos esses escritos iam sendo elaborados a partir de uma solida convicção de que o catolicismo representava a "única religião verdadeira" e que a igreja era o único caminho de salvação (WHEATCROFT, 2008, p.175).

Ao chegar os missionários em solo brasileiro tinham diversas compreensões do que eram a religião, divindades, culto e ritual, obviamente que na perspectiva protestante e católica. Visto que o resultado do registro missionário dependia do momento e das circunstâncias da atuação da ordem religiosa a que pertenciam e do projeto em que estavam inseridos.

Esta situação documental exige a constituição de uma análise critica como por exemplo: 1. Quem escrevia? 2. A quem? 3. Porque escrevia sobre a sua religiosidade? 4. Que interesse levaram a escrever? 5. Em que circunstâncias escreviam? 6. Em que tipo ou modelo de escrita escreviam? é necessário perceber que antes da chegada dos católicos e protestantes no Brasil os indígenas/tupinambás já tinham a sua religiosidade, espiritualidade e crença em um Deus.

Enfim, o cristianismo se expandiu na América num marco colonial de união da Igreja e do Estado e as conquistas ofereceriam poucas

15 Sergio Buarque de Holanda (historiador); Darcy (antropólogo, político e escritor); Hans Staden; Jean de Léry; André de Thévet; Manuel da Nobrega; José de Anchieta; Florestan Fernandes; Manuel José de Araújo Porto-alegre; Claude d'Abbeville; Momborê-auçu; Martim Afonso de Souza; Duarte Coelho Pereira; Tomé de Souza e Francisco Adolfo de Varnhagen. ADÃO, Maria Cecília Oliveira; SANCHES, Everton Luis; SALDANHA, Flávio Henrique Dias. História do Brasil I. São Paulo: CLARETIANO, 2013, p. 38-41.

16 WACHHOLZ, Wilhelm. A conquista e evangelização no Brasil. São Leopoldo: Faculdades EST, 2008, p.9-12.

17 WHEATCROFT,Op. cit.,p. 175. 
alternativas aos estados, às linguagens indígenas nobres ou às lideranças que reconheciam os europeus.

Os protestantes e católicos negociavam e entravam em acordos com os indígenas obrigando-os em primeiro lugar a aceitarem a fé protestante/católica. Se não aceitassem, eram considerados como rebeldes e bárbaros que poderiam ser atacados e transformados em escravos no marco de uma guerra que em termos de fé era considerada justa.

A partir da segunda metade do século XIX mudou-se a forma de entender as culturas e, no período contemporâneo, passou-se a perceber que as culturas não são impermeáveis ou impenetráveis, mas que elas podem manter-se, fundir-se com outras e também se sobrepor a outras.

\section{As correntes liberais versus protestantismo de imigração}

Os modernizadores liberais permitiram o ingresso do protestantismo no Brasil no século XIX. Em geral, acreditava-se que o protestantismo ${ }^{18}$ era responsável pela transição para uma sociedade moderna. O protestantismo seria a religião que criasse o espírito do progresso (DUSSEL, 1992, p.70).

Este "espírito" também foi pregado pelos missionários protestantes que vieram para o Brasil no século XIX e defendiam que todo mundo seria salvo à maneira de ser americana ou à maneira alemã. Neste sentido a pregação do tipo evangelístico transformava o convertido em tipo ideal para a nova sociedade desejada. O outro lado desta "moeda" foi o anticatolicismo.

$\mathrm{Na}$ verdade, esse modelo entrou em crise quando o projeto liberal modernizador também entrou em crise. Pelo fato de se aliar à classe média e esta ser mais sacrificado economicamente o protestantismo também entrou em crise. A partir daí o empobrecimento da classe média suscitava a seguinte pergunta: Será que nossa fé não funciona mais?

Camargo (1973, p.106) relata-nos que o protestantismo ${ }^{19}$ no Brasil surgiu a partir de 1819/1824, como resultante da vinda de imigrantes oriundos de territórios que correspondem às atuais como a Alemanha, a

18 DUSSEL, Enrique. História Liberationis - 500 anos de história da Igreja na América Latina. São Paulo: Paulinas, 1992, p. 70.

19 CAMARGO, F.P. Cândido. Católicos, protestantes e Espiritas. São Paulo: Vozes, 1973, pg,.106 
Suíça, a Holanda, a Polônia, a Escandinávia, a Áustria e ainda outros. Dussel informa-nos que durante o Brasil Império ${ }^{20}$ os protestantes de imigração foram relegados à sua própria "sorte" e que também a Velha República não os resgatou do isolamento a que estavam expostos. Por isso, o pangermanismo alemão encontrou neles solo fértil. As medidas nacionalizadoras novamente os marginalizaram, antes da segunda guerra mundial, por isso muitos destes protestantes aderiram ao nazi-fascismo ou ao integralismo conhecido como movimento de direita - Ação integralista brasileira, com vestes fascistas, sob a liderança de Plínio Salgado (DUSSEL, 1993, p.107).

Diante da impossibilidade de se reeleger, pois o terceiro mandato seria inconstitucional, Getúlio Vargas declarou o golpe de estado em 10 de novembro de 1937, antecipando-se às eleições que deveriam ocorrer em janeiro de 1937, isto porque a ação integralista brasileira ${ }^{21}$ desejava substituir o pluralismo político partidário por um partido nacionalista autoritário e promover a unidade brasileira, formando um povo a partir dos diferentes povos e raças, e eliminar a corrupção. $\mathrm{O}$ projeto fracassou, pois Vargas já tinha uma base de apoio político - os sindicatos de trabalhadores. Hábil político, ele jogou a esquerda, partido comunista (1922), contra a direita, eliminando em 1935 os comunistas com apoio dos integralistas e partidos burgueses que se apavoravam com a possibilidade comunista (DREHER, 2007, p.230).

Afinal, o ingresso do Brasil na segunda guerra mundial deu uma sacudida final nos protestantes de imigração e a partir de 1945 houve um progressivo abandono da língua alemã e a nacionalização do clero e crescente envolvimento em assuntos nacionais.

\section{Alguns ramos da reforma protestante no Brasil}

Observando a imigração ${ }^{22}$ protestante no Brasil não podemos deixar de citar alguns dos pioneiros e historiadores do protestantismo brasileiro e são eles: Émile G. Léonard que de um lado relata tanto a importância da reforma protestante na Alemanha como de outro lado, apresenta a

${ }_{20}$ DUSSEL.Op., cit., p. 107.

21 DREHER, N. Martin. A Igreja Latino-Americana no Contexto Mundial. $3^{\circ}$ edição. São Leopoldo: Sinodal, 2007, p. 230.

22 MENDONÇA, G. Antônio. Introdução ao protestantismo brasileiro. São Paulo: Loyola, 2002, p. $16-17$. 
estranha configuração das igrejas da reforma no país achando-as distorcidas e afastadas em muitos aspectos do movimento religioso do século XVI (MENDONÇA, 2002, p.16-17).

Léonard afirma em seu livro "O protestantismo brasileiro", [...] que o protestantismo missionário não veio do continente europeu, mas dos Estados Unidos, cujo protestantismo tinha raízes na reforma inglesa [...], mas isto se verá mais adiante. Émile Léonard (2002, p.252) nos proporciona um quadro ${ }^{23}$ dos ramos do protestantismo no Brasil, de origem migratória e de origem missionária e pentecostal, vejamos a seguir:

PRINCIPAIS IGREJAS ORIUNDAS DO PROTESTANTISMO DE IMIGRAÇÃO:

\section{"ANGLICANO"}

Anglicanismo propriamente dito (ingleses e seus descendentes); Episcopais (de origem norte-americana; brasileiros; japoneses e seus descendentes);

Metodistas* (de origem do Sul dos Estados Unidos; brasileiros).

LUTERANO

Luteranos ligados à Alemanha (Igreja Evangélica de Confissão Luterana* do Brasil; alemães e seus descendentes);

Luteranos ligados aos Estados Unidos (Sínodo de Missouri; Igreja Evangélica Luterana do Brasil; alemães e seus descendentes);

PRINCIPAIS IGREJAS PROTESTANTES DE MISSÃO REFORMADO

Presbiterianos (missões norte-americanas; brasileiros);

Congregacionais (missões inglesas, norte-americanas e outras; brasileiros);

Reformados europeus - Igrejas de colônias (holandeses, húngaros, franceses e etc).

23 LÉONARD, G. Émile. O protestantismo brasileiro. $3^{\circ}$ edição. São Paulo: ASTE, 2002. p. 352.

* LÉONARD.Op., cit., p. 241. 


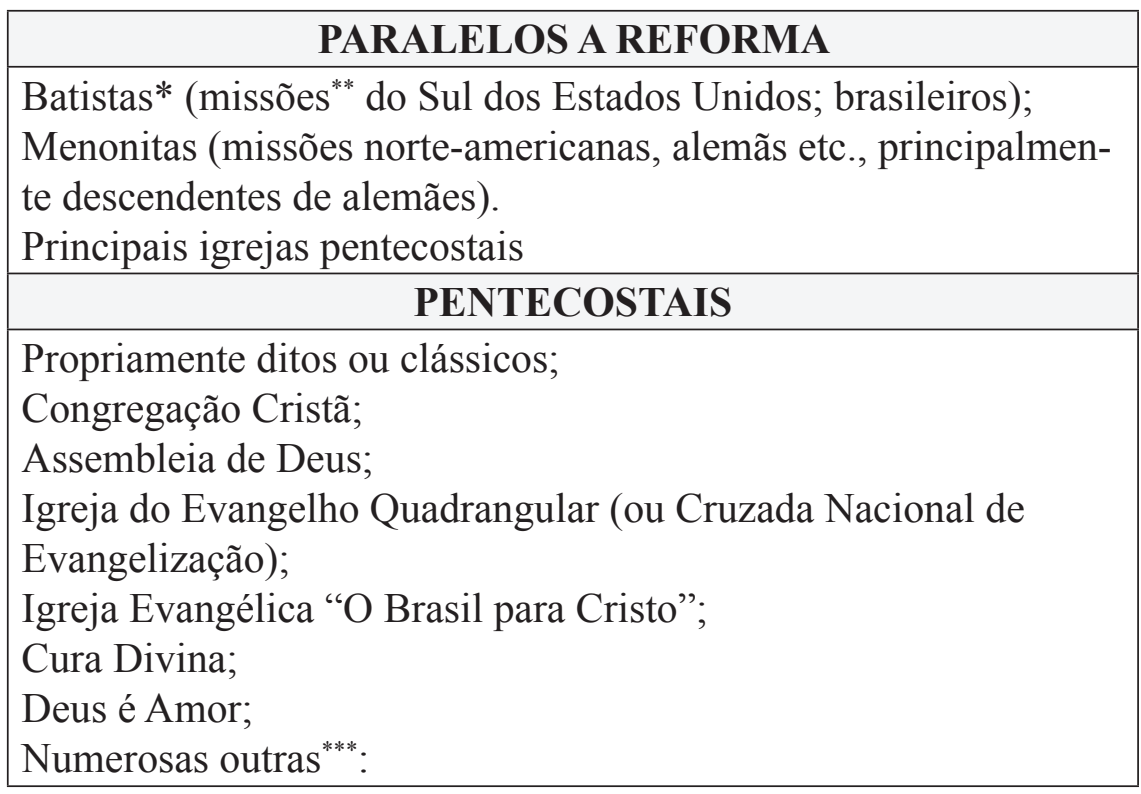

O quadro em referência não esgota as igrejas protestantes no Brasil, nem quanto às históricas e muito menos quanto às pentecostais porque a maioria dos seus fundadores migraram das igrejas que denominamos dos grupos do protestantismo de missão.

\section{O protestantismo de Missão}

Como estávamos relatando anteriormente sobre o protestantismo de missão, antes de descrevermos os ramos do protestantismo no Brasil, Émile G. Léonard levanta a hipótese de que o protestantismo de missão quando chegou ao Brasil tinha intenções fortemente pragmáticas e pretendia ser elemento transformador da sociedade através da transformação dos indivíduos.

Embora o pragmatismo caracterize o protestantismo no Brasil, este protestantismo está ligado, na medida em que se expressa através de igrejas, à reforma do século XVI. Contudo, a reforma foi reforma

\footnotetext{
** LÉONARD.Op., cit., p. 242-243.

*** Nesta tabela inserimos o sinal (*) entre os metodistas e batistas, por acreditarmos que estas duas denominações fazem parte do protestantismo de missão. Quanto às igrejas pentecostais incluídas, acreditamos que entraram na lista devido ao fato de alguns de seus fundadores terem saído ou migrado do protestantismo de missão.
} 
da igreja e não da teologia, esta sofreu somente ênfases, arranjos e rearranjos etc.

Este pragmatismo da religião civil norte-americana em que a eficácia das ações era validada pela prática religiosa levou Émile Léonard a comparar o protestantismo brasileiro com o europeu, ao declarar "este adora, enquanto que aquele trabalha". O culto ${ }^{24}$ protestante no Brasil é bem diferente do Católico Romano que na verdade é simbólico e ritualizado, e os seus agentes, clérigos ou leigos, são obreiros, conforme o posicionamento de Mendonça (2008, p.148).

Segundo o autor, nos Estados Unidos os puritanos "trabalharam" para construir uma nação. Segundo este modelo no Brasil os protestantes tem "trabalhado" para transformar a sociedade civil. Não cabe a comparação entre os protestantes brasileiros e os europeus, devido à religião ter na Europa outra finalidade, isto é, adorar a Deus.

O protestantismo de missão diferentemente do de imigração ${ }^{25}$, chegou ao Brasil sem povo e então eles tiveram de "ganhar pessoas" para si. A primeira tentativa de instalação do protestantismo (1835-1841) fracassou. A Igreja Metodista Episcopal dos EUA enviara Foutain Pitts, ao Rio de Janeiro e no ano seguinte enviou Justin R. Spaulding, o qual criou uma Escola Dominical, mas eles não tinham muitos recursos. No ano de 1837 chegou Daniel P. Kidder que ficou na missão até 1841 quanto teve que retornar aos EUA infelizmente por consequência da falta de recursos (DUSSEL, 1981, p.139-164).

O trabalho de ensinamento bíblico ${ }^{26}$ contínuo com James C. Fletcher, pastor presbiteriano e secretário da embaixada Americana no Rio de Janeiro. Aliando a religião e o comércio tornou-se um autêntico representante protestante do projeto liberal modernizador. Fletcher foi quem entrou em contato com Robert R. Kelley um médico escocês com passagem pela Ilha da madeira e residente nos EUA. Convidou-o para vir ao Brasil o que só concretizou-se em 1855. Ele veio com sua querida esposa Sarah Poulton Kalley e enraizado em Petrópolis, fundou a

24 MENDONÇA, G. Antônio. O celeste porvir - A inserção do protestantismo no Brasil. São Paulo: EDUSP, 2008. p, 148.

25 DUSSEL, Enrique. História da Teologia na América Latina. São Paulo: Paulinas, 1981. p. 139-164.

26 MENDONÇA.Op., cit., p.149-155. 
Igreja Evangélica Fluminense que hoje se denomina Igreja Evangélica Congregacional do Brasil (MENDONÇA, 2005, p. 149, 155).

Quatro anos após da chegada de Kelley, a Igreja Presbiteriana dos EUA enviou para o Brasil em 1859 Ashbel Green Simonton, que se estabeleceu no Rio de Janeiro onde em (1862) fundou a primeira igreja. Infelizmente Simonton faleceu em 1867 não vendo o grande desenvolvimento desta igreja, que já existe há 150 anos em solo brasileiro.

Outro missionário enviado para o Brasil, mas este para a cidade de São Paulo foi Alexandre Latimer Blackford. O trabalho deste missionário parecia não se desenvolver, mas com a conversão do Padre José Manoel da Conceição ao presbiterianismo, no entanto, alavancou o trabalho missionário e foi o ex-padre que passou a pregar nos lugares onde antes era vigário nas rotas do café de São Paulo.

Mas, o grande impulso do protestantismo de missão se deu a partir da década de 1870 em conseqüência da Guerra de Secessão nos EUA. Está guerra se estendeu de 1861 à 1865 . Na época da Independência dos EUA (1776) não faltavam vozes que desejavam o nascimento de uma nação "limpa", isto é, livre da escravidão.

No entanto, para não ocorrer um esfacelamento das forças diante da Inglaterra o assunto foi silenciado novamente, por outro lado, a Igreja Metodista excluía donos de escravos de seu meio.

A Igreja Batista embora não chegasse a fazer o mesmo defendia ideias abolicionistas, mas, com o passar do tempo com o intuito de atrair os brancos do sul dos EUA, onde a escravidão se concentrava, batistas e metodistas foram se amoldando à escravidão de forma que, em 1843, cerca de 1.200 ministros e pregadores possuíam cerca de 1500 escravos.

A Igreja Presbiteriana ${ }^{27}$ de forma ambígua declarava que a escravidão era contrária à vontade de Deus, mas, ao mesmo tempo, declarava-se contra a abolição. Pouco a pouco, no entanto, ideias abolicionistas foram tomando forma no norte. Na região do sul dos EUA que dependia da mão de obra escrava neste período historiográfico surgiram vários posicionamentos em relação à escravidão e uma das argumentações era que a escravidão era vontade divina e isto cada vez mais foi sendo propagado (DREHER, 2007, p.236-238).

27 DREHER, N. Martin. A Igreja Latino-Americana no Contexto Mundial. $3^{\circ}$ edição. São Leopoldo: Sinodal, 2007,. p. 236-238. 
Justificavam-se estas abordagens afirmando que, se os negros tivessem permanecido na África nunca teriam ouvido a mensagem do evangelho. Os preços só aumentavam e os Metodistas do sul decidiram romper com os do norte em 1844 e, no ano seguinte fundaram a "Igreja Metodista Episcopal do Sul".

O mesmo aconteceu com os Batistas do Sul que fundaram a Convenção Batista do Sul e com os presbiterianos do sul (estes em 1857). Em 1861, seis estados sulistas romperam com o resto da nação e fundaram os Estados Confederados da América o que redundou em guerra.

As igrejas do sul e do norte apoiaram respectivamente suas causas e após a derrota da confederação as igrejas do sul preferiram continuar separadas das irmãs do norte, enquanto a tensão entre negros e brancos do sul continuava grande. Destas tensões surgiu a "Ku Klux Klan", que inclusive tinha membros de igrejas em seu meio. Acordos dos magnatas do norte com os brancos do sul tornaram esta região colônia econômica do norte.

Com isso, podemos argumentar que as igrejas do sul continuaram seu racismo o que levou ao surgimento de igrejas negras separadas das de brancos e foram as igrejas do norte, particularmente a presbiteriana e a metodista que se dedicaram aos negros do sul de forma que a maioria dos negros do sul pertencia a igrejas do norte.

\section{Considerações finais}

Neste ensaio apresentamos de forma bem resumida um histórico do protestantismo de imigração e de missão no Brasil, focando a atenção nos principais personagens fundadores de igrejas em solo brasileiro, desde o século XVI até o século XIX. Demos particular ênfase às primeiras tentativas de inserção, com a França Antártica no século XVI e o Nordeste holandês no século XVIII. Apresentamos também um quadro das diversas formas de protestantismo no Brasil atual.

\section{Referências}

ALENCAR, Gedeon. Protestantismo Tupiniquim. Hipóteses sobre a (não) contribuição evangélica à cultura brasileira. São Paulo: Arte editorial, 2005.

ADÃO, Maria Cecília Oliveira; SANCHES, Everton Luis; SALDANHA, Flávio Henrique Dias. História do Brasil I. São Paulo: CLARETIANO, 2013. 
BASTIAN, Jean-Pierre. O Protestantismo na América Latina. São Paulo: Paulinas, 1998.

BUCKE, S.E. The history of American Methodism. $3^{\circ}$ ed. Londres, 1981.

CURTIS, Kenneth. A. Os 100 acontecimentos mais importantes da história do Cristianismo. São Paulo: Vida.

BREDA, Daniel Oliveira. Vicus Judaeorum: Os Judeus e o espaço urbano do Recife Neerlandês (1630-1654). Dissertação (Mestrado) - Centro de Ciências Humanas, Letras e Artes - Departamento de História, Universidade Federal do Rio Grande do Norte, 2007, 253p.

DREHER, N. Martin. A Igreja Latino-Americana no Contexto Mundial. $3^{\circ}$ edição. São Leopoldo: Sinodal, 2007.

DUSSEL, Enrique. Historia Liberationis; 500 anos de história da Igreja na América Latina. São Paulo: Paulinas, 1992.

DUSSEL, Enrique. 1492. O Encobrimento do Ouro, a origem do mito da modernidade. Petrópolis: Vozes, 1993

DUNSTAN, J. Leslie. Protestantismo. Lisboa, Verbo, 1980

ELWELL, A. Walter. Enciclopédia Histórica Teológica da Igreja Cristã. São Paulo: Vozes, 1994

FERREIRA, L. C. João. Novas perspectivas sobre o protestantismo brasileiro. São Paulo: Paulinas, 2009.

GONZALEZ, Justo L. A Era dos Conquistadores. São Paulo: Vida Nova, 1983 (Uma História Ilustrada do Cristianismo, 7).

GRIJP, Klaus van der. As Missões Protestantes. In: HOORNAERT, Eduardo, et. al. História da Igreja no Brasil; ensaio de interpretação a partir do povo; primeira época. São Paulo: Paulinas; Petrópolis: Vozes, 1992.

MENDONÇA, A. Antônio; FILHO, Velasques Prócoro. Introdução ao protestantismo no Brasil. $2^{\circ}$ edição. São Paulo: Loyola, 2002, p. $11-12$.

MENDONÇA, G. Antonio. O protestantismo e suas encruzilhadas. Revista USP/São Paulo, n.67, p. 48-67, setembro/novembro, 2005.

MENDONÇA, A. Andrey. Origens do protestantismo: da Europa às terras brasileiras. São Paulo: FTBSP, 2009.

NORWOOD, A.F. Sourcebook of American Methodism. EUA. 1990

SILVA, Haroldo Xavier. Protestantismo e conceitos. São Paulo: Faculdade Batista de São Paulo, 2015.

WHEATCROFT, Andrew. Infiéis, o conflito entre cristandade e o Islã. São Paulo: Imago, 2004. 
no Brasil: história, cultura e tradição

WALTER, W. História da Igreja Cristã. São Paulo: Aste, 2006.

WACHHOLZ, Wilhelm. A conquista e evangelização no Brasil. São Leopoldo: Faculdades EST, 2008. 